Интернет-журнал «Науковедение» ISSN 2223-5167 http://naukovedenie.ru/

Выпуск 6 (25) 2014 ноябрь - декабрь http://naukovedenie.ru/index.php?p=issue-6-14

URL статьи: http://naukovedenie.ru/PDF/129TVN614.pdf

DOI: 10.15862/129TVN614 (http://dx.doi.org/10.15862/129TVN614)

Chokhonelidze Alexander Nikolayevich

Tver state technical university

Russia, Tver

E-mail: a444595@pochta.ru

Forgor Lempogo

Tver state technical university

Russia, Tver

Ghana technology university

Ghana, Accra

E-mail: forlempo@yahoo.co.nz

Brown-Acquaye William

Tver state technical university

Russia, Tver

Ghana technology university

Ghana, Accra

E-mail: wbrownacquaye@ hotmail.com

\title{
Automated control of heat treatment process of cocoa beans using PID controllers
}




\begin{abstract}
Thermal treatment processes such as roasting and drying are very energy intensive and considering the ever-increasing cost of energy, there is the need for continuous process improvement in order to reduce operational cost, while maintaining or improving the quality of the end cocoa products. This work describes the design and simulation of an automated control system (ACS) based on a PID controller algorithm for the control of the thermal treatment of cocoa beans in a conveyor belt dryer. The thermal treatment processes is modelled as a continuous, spatially distributed single input single output system (SISO), where the control variable is the temperature of the inlet drying air and the controlled variable, the product temperature in the drying chamber. Software and hardware requirement of the ACS were also presented and discuss. Numerical simulations of the ACS were carried out using Matlab and Simulink. Overall, the numerical simulation results show that the PID controller is stable and robust in terms of input disturbance rejection. The system provides relatively fast response in terms of eliminating offset and steady state error in the thermal treatment process.
\end{abstract}

Keywords: PID controller; heat treatment; cocoa; automated control; control strategy; mathematical modeling.

\title{
Ссылка для цитирования этой статьи:
}

Чохонелидзе А.Н., Форгор Лемпого, Виллиам Браун-Аквей Автоматизированное управление процессом термообработки какао-бобов с использованием ПИД-регулятора // Интернет-журнал «НАУКОВЕДЕНИЕ» 2014. № 6 http://naukovedenie.ru/PDF/129TVN614.pdf (доступ свободный). Загл. с экрана. Яз. рус., англ. DOI: $10.15862 / 129$ TVN614 


\section{Introduction}

As the basic raw material for chocolate and many other chocolate-based products, cocoa beans go through different technological processes before they end up with the final consumer. Thermal sub processes are a significant part of cocoa processing, where by cocoa beans, paste or mixture are exposed to an elevated temperature for a period of time to make them suitable for handling, consumption or incorporation into further processing. The main aim of thermal treatment is to extend shelf life by reducing bacterial counts to acceptable levels, and to produce a desirable cocoa aroma and flavor in the product. [1] [2] Among the most prominent thermal sub processes in cocoa processing, are the drying of beans by smallholder farmers, roasting of beans and drying instant cocoa powder. The ultimate quality of cocoa beans, whatever their origin, is significantly affected among other factors, by the conditions of thermal treatment [3].

Thermal treatment processes such as roasting and drying are very energy intensive and considering the ever-increasing cost of energy, there is the need for continuous process improvement in order to reduce energy requirement (to reduce operational cost), while maintaining or improving quality indicators of the end cocoa products [4] [5] [6]. These can be achieved through effective automation and control of such processes [7].

Automated control of thermal treatment process of food and agricultural produce has always been a challenging task for engineers and researchers in the industry. This is due to the long process delays and the prevalence of non-linearity and parameter uncertainties in such processes [8]. The most inexpensive, but robust and reliable way of implementing automated control of a process is through the use proportional-integral-derivative (PID) controllers.

In this work, an automated control system (ACS) based on a PID controller algorithm is proposed for the control of the thermal treatment of cocoa beans.

\section{Control Strategy of the thermal treatment process}

The main control objectives of thermal processing systems include, maintaining the desired product temperature in the presence of disturbances in the process; maximizing product output rate while maintaining optimal operational costs; avoiding over drying (which increases energy costs and can cause thermal damage to heat-sensitive solids) and under drying (which leads to mold growth) and stabilizing the overall process. [9, 10, 7, 11].

The main criteria of optimization of heat treatment processes of cocoa beans is dependent on the changing process conditions, such as the quality of the final product, the specific energy consumption (per unit mass of evaporated moisture) and the duration of the process $[12,7,10]$. With convective heat treatment process, these conditions (product quality, process energy and duration) are highly dependent on temperature of the drying chamber. Intensification of the process is achieved by increasing the temperature of the drying chamber, which in turn depends on the temperature of the input drying air. As a result, the control problem of thermal cocoa beans processing is reduced to controlling heat supply so that the beans are quickly heated to an acceptable temperature, and then remains constant throughout the whole process.

There are diverse control approaches and methods for thermal treatment processes of bulk materials in various heat treatment equipment $[7,11,9,13,14]$. In our drying system setup, we can speed up the heating process by adjusting the heater temperature at the beginning of the process to allow for the heating to the maximum allowable temperature gradients $\left(\mathrm{T}_{\max }\right)$ for the bed of cocoa beans. The heater is then readjusted to maintain a constant temperature after the bed is heated to the set temperature $\left(\mathrm{T}_{\mathrm{set}}\right)$. In this case, the plant can be modelled as a spatially distributed single input single output system (SISO) where the control variables is the temperature of the inlet drying air $\left(\mathrm{T}_{\mathrm{c}}\right)$ and the controlled variable the product temperature $(\mathrm{T})$ in the drying chamber. 


\section{Mathematical model}

The heat treatment of foods and other biological materials such as cocoa beans takes place in a drying chamber where the bed of beans is exposed to a hot-air flux. During convective heat treatment, two transport mechanisms simultaneously occur in the chamber:

1. Transfer of heat energy from the hot air to the surface of the beans through convection and subsequent transfer of the energy to the interior of the beans through conduction;

2. Transfer of moisture from inside the bed to its surface through diffusion and the subsequent transfer of moisture from the surface layer into the air by evaporation (see Fig. 1).

Input parameters for the mathematical model include the initial temperature of the cocoa beans and the drying air, height and length of the bed, etc. In developing the mathematical model, the bed of cocoa beans in the convective heat-treatment equipment is considered as a homogeneous hygroscopic plate, which heat treatment process goes through three periods: the heating, constant rate and falling rate.

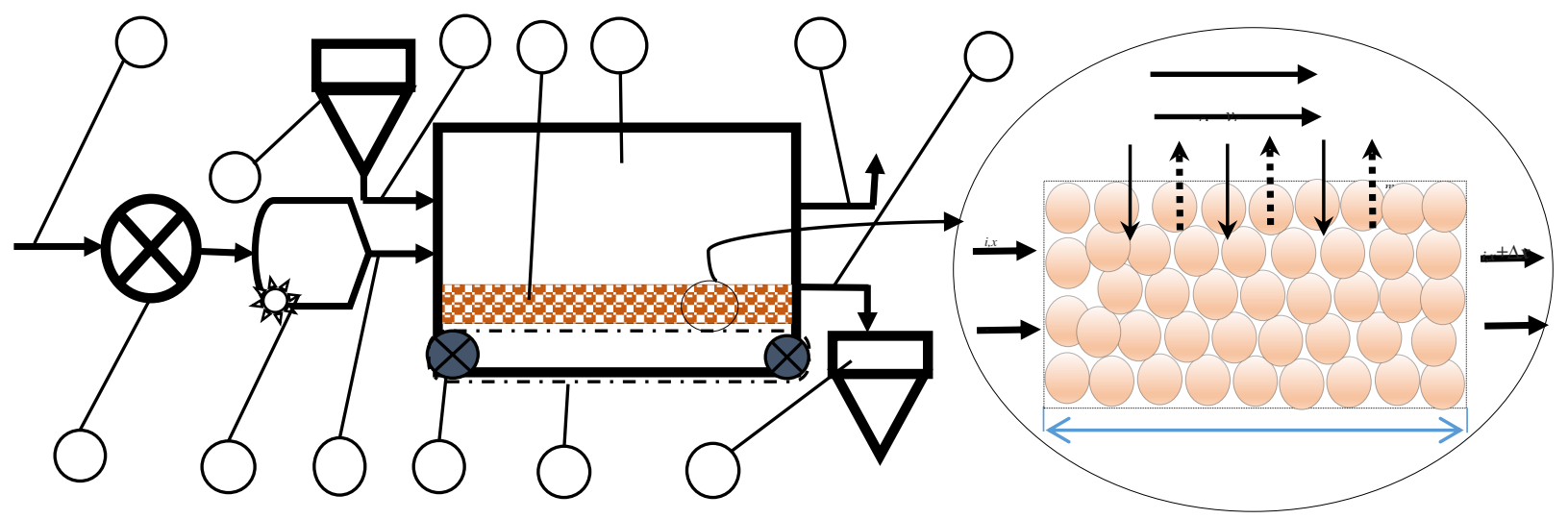

Fig. 1. Scheme of a pilot plant for heat treatment of cocoa beans

Where:

1 - Entrance to the chamber; 2 - wet cocoa beans; 3 - bed of cocoa beans; 4 - conveyor belt; 5 - drying chamber; 6 - dried cocoa beans; 7 - cyclone; 8 - belt motor; 9 - inlet drying air; 10 electric fan / blower; 11 - electric heater; 12 - hot drying air; 13 - humid exit air; $\mathrm{U}_{0}$ - initial moisture content; $\mathrm{U}_{\mathrm{f}}$ - final moisture content; $\mathrm{l}_{\mathrm{c}}$ - flow rate of drying air; $\mathrm{I}_{\mathrm{f}}-$ flow rate of outlet air; $\mathrm{T}_{\mathrm{c}}-$ temperature of the drying air; $T_{f}-$ temperature of the outlet drying air; $V_{c}-$ speed of drying air; $J_{e}-$ heat flux; $\mathrm{J}_{\mathrm{m}}$ - moisture flux; $\varsigma$ - length of the bed; $\mathrm{x}$ - coordinates.

The energy transfer equation for the heating period:

$$
\left\{\begin{array}{c}
\frac{\partial T(x, \tau)}{\partial \tau}=a_{p} \frac{\partial T^{2}(x, \tau)}{\partial x^{2}} \\
\left(\begin{array}{l}
\tau>0, \\
-\ell<x<\ell
\end{array}\right)
\end{array} ;\right.
$$

With initial and boundary conditions:

$$
\frac{\partial T(0, \tau)}{\partial x}=0 ; \quad T(x, 0)=T_{0}=\text { const } ;
$$




$$
-\lambda_{p} \frac{\partial T(\ell, \tau)}{\partial x}+\left[T_{c}-T(\ell, \tau)\right]=0,
$$

For the constant rate period, the equation of energy will be:

$$
\frac{\partial T(x, \tau)}{\partial \tau}=a_{p} \frac{\partial^{2} T(x, \tau)}{\partial x^{2}}+\frac{q_{v}}{c_{p} \rho_{p}} ;
$$

With initial and boundary conditions:

$$
\begin{gathered}
T(x, 0)=T^{*} \\
\frac{\partial T(0, \tau)}{\partial x}=0 ; \\
\frac{\partial T(\ell, \tau)}{\partial x}+\frac{\alpha}{\lambda_{p}}\left(T_{c}-T(\ell, \tau)\right)=0,
\end{gathered}
$$

The heat source, resulting from the reaction of enzymatic browning of cocoa beans in the heat treatment process is given in [15] by the equation:

$$
q_{v}=q_{\Sigma} k \exp \left[-\frac{U}{R T}\right]
$$

Where, a - thermal diffusivity; $\mathrm{c}$ - specific heat; $\mathrm{k}$ - rate constant; $\mathrm{q}$ - heat source term; $\mathrm{T}$ temperature; U - humidity beans; V - velocity of the medium; $\mathrm{x}$ - coordinate; $\alpha$ - heat transfer coefficient; $\tau$ - time; $\ell$ - The thickness of the layer; $* \mathrm{~T}$ - temperature at the start of the second period; $\lambda$ - thermal conductivity of the layer; $\rho$ - density of the layer; $U$ - activating energy; universal gas constant. Index: 0 - initial; $\mathrm{c}$ - air; e - heat; $\mathrm{p}$ - the product; $\Sigma$ - cumulative effect; $\mathrm{v}$ - total.

\section{The Automated Control system}

The first step in developing a process control system is the design of a functional scheme of automation. This involves identifying all the functions of the system, its tiered decomposition, the choice of instrumentation, actuators and control devices [14]. The proposed automated control system of heat treatment of cocoa beans has a modular structure (see. Fig. 2). This include the user interface module for the system operator, the plant module, the controller unit and the data management module. 


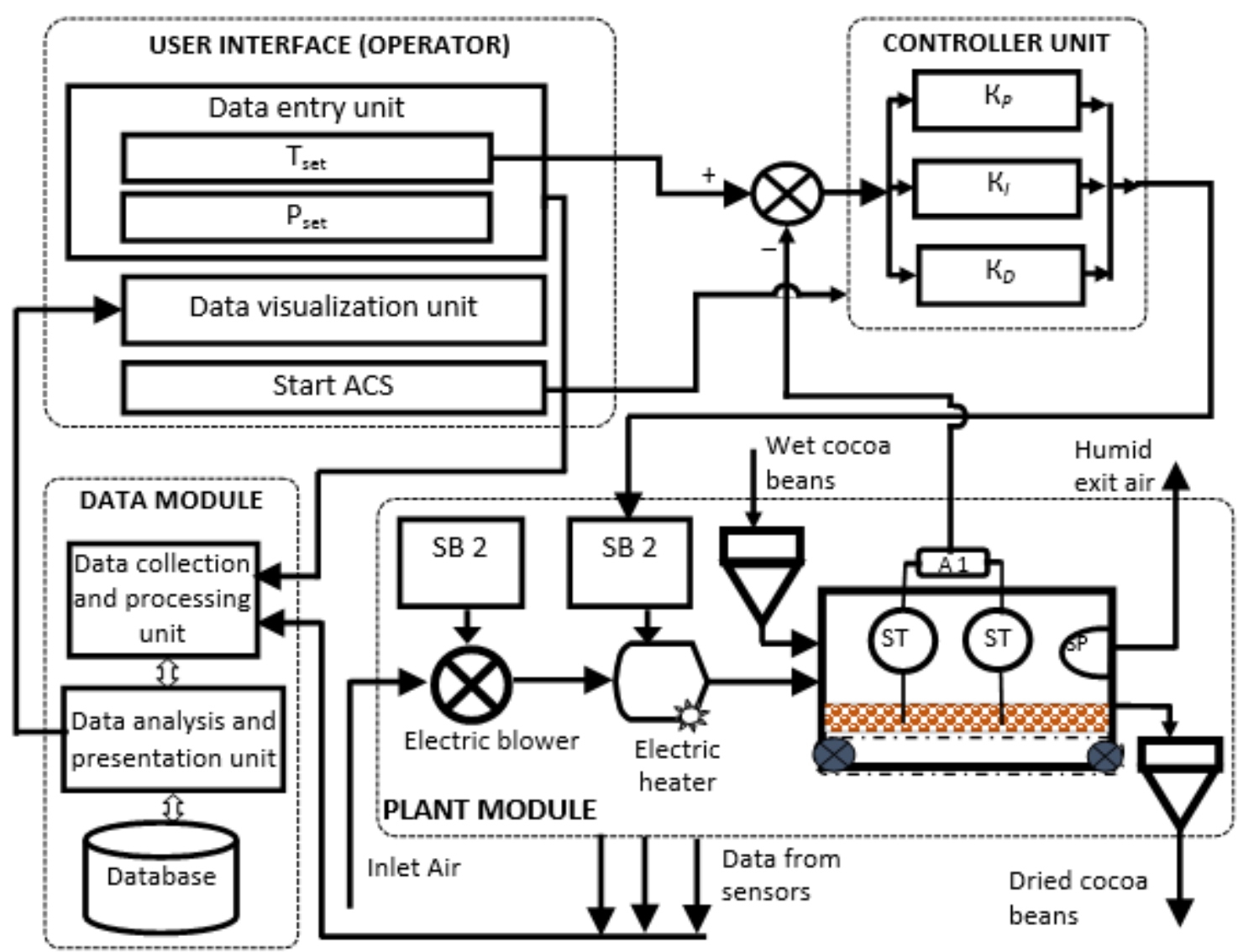

Fig. 2. Functional scheme of the automated control system for the heat treatment of cocoa beans

Where, $\mathrm{T}_{\text {set }}-$ set temperature; $\mathrm{P}_{\text {set }}-$ set pressure; $\mathrm{SB} 1$ - voltage controlled switchboard for the blower; SB 2 - voltage controlled switchboard for the heater; ST1 и ST2 - temperature sensors; SP - pressure sensors.

There are two important information sources in control systems: sensors, which provide numerical measurements of variables, and human operator who gives instructions and descriptions about the process $[7,16]$. The operator interacts with the automated control system (ACS) through the graphical user interface of the controller software on a personal computer. The operator uses this module to set parameters and to view current process information about the state of the heat treatment process.

The plant is made up of the conveyor belt dryer with a belt of surface $1 \mathrm{~m} \mathrm{x} 4.5 \mathrm{~m}$, and a set of sensors, i.e. temperature and pressure sensors etc. An adjustable electric heater $(24 \mathrm{~kW})$ is used to heat the drying air and is controlled by a PID controller that maintains temperature with feedback from a K-type thermocouple inside the bed of beans in the chamber. The thermocouples measure the bed temperatures at regular intervals and pass the average measured value to the controller module through an A/D board. A Remote addressable units (PAX2C Dual Line 1/8 DIN Intelligent Meter Series, Red Lion Controls Inc.) is used to accept set point values from the control computer. The operator adjusts both the beans flow rate and the heater temperature to regulate the rate of heating. The height of the bed varies with loading rate and the conveyor speed.

The data module contains the mechanisms for collecting, processing and storage of the process data in a relational database. This maintain a log of process information required for quality assurance purposes. It is also necessary in order to evaluate the controller performance. The ACS has two operation modes, automatic and manual modes of control, but in both modes, the system continues to $\log$ and display data. 
The controller unit uses a PID feedback control algorithm with a negative feedback (See fig. 3 ). The PID controller is the most common form of feedback and makes up more than $95 \%$ of the control loops in the process industry. [17] It is made up of three correcting terms (proportional, integral, and derivative, denoted by $\mathrm{K}_{\mathrm{P}}, \mathrm{K}_{\mathrm{I}}$, and $\mathrm{K}_{\mathrm{D}}$ ), the sum of which constitutes the control action. The SISO PID control loop considered in this paper is shown in figure 3.

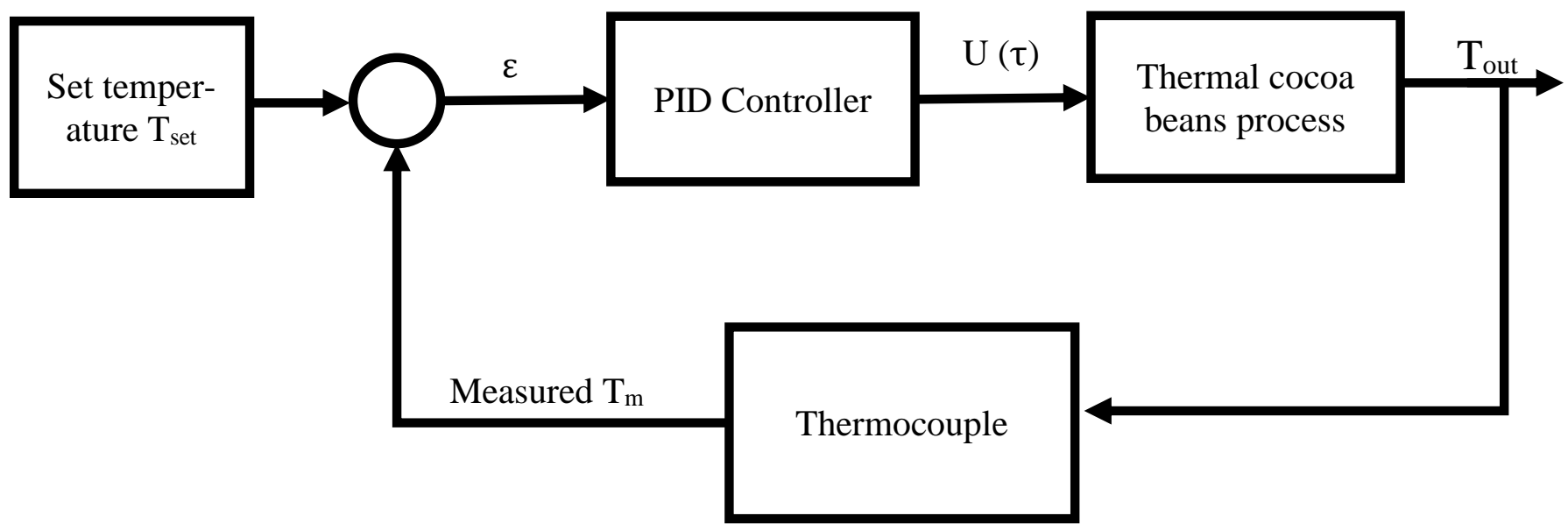

Fig. 3. Block diagram of the feedback controller

The control action $\mathrm{U}(\tau)$ for a PID algorithm according to [18] has the form:

$$
U(\tau)=K_{c} \varepsilon+K_{c} \tau_{D} \frac{d \varepsilon}{d t}+\frac{K_{c}}{\tau_{I}} \int_{0}^{t} \varepsilon d t+p_{s}
$$

Where $\mathrm{K}_{\mathrm{c}}$ is the proportional gain, or sensitivity; $\varepsilon$ is the error = (set point) - (measured variable); $p_{\mathrm{s}}$ is a constant, the steady-state output from the controller [the bias value]; $\tau_{\mathrm{I}}$ and $\tau_{\mathrm{D}}$ are the integral and derivative time in minutes, respectively.

The transfer function for a PID controller can be obtained from the Laplace transform of equation (9) to get $[19,20,18]$ :

$$
\frac{U(s)}{\varepsilon(s)}=K_{c}\left(1+\tau_{D} s+\frac{1}{\tau_{I} s}\right)
$$

In order to obtain a process transfer function, a linear model of the system is obtained by linearizing equations (1) - (8) using Taylor series expansion and finding the Laplace transform of the resulting linear equation using the procedure in [21]. The resulting equation in the s domain is then simplified using the transmission matrix method, as described in $[22,23]$ and thermal process parameters (as shown in table 1) were substituted in the final equation to achieve the simplified process transfer function:

$$
G_{p}(s)=\frac{0.397}{0.25 s+0.00312}
$$


Table 1

Process parameters of the thermal processing of cocoa beans

\begin{tabular}{|l|l|l|l|}
\hline \multicolumn{1}{|c|}{ Parameter } & \multicolumn{1}{c|}{ Symbol } & \multicolumn{1}{c|}{ Value } & \multicolumn{1}{c|}{ Unit } \\
\hline Heat of reaction & $\mathrm{q}_{\Sigma}$ & 2402 & $\mathrm{~J} / \mathrm{kg}$ \\
\hline Reaction constant & $\mathrm{K}_{0}$ & 0.074258 & - \\
\hline Activation energy & $\mathrm{U}$ & 22.48 & $\mathrm{~kJ} / \mathrm{mol}$ \\
\hline Universal gas constant & $\mathrm{R}$ & 8310 & $\mathrm{~J} / \mathrm{kmol} \mathrm{K}$ \\
\hline Ambient temperature of beans & $\mathrm{T}_{0}$ & 293 & $\mathrm{~K}$ \\
\hline Thermal diffusivity & $\mathrm{a}_{\mathrm{p}}$ & $3,79.10^{-5}$ & $\mathrm{~m}^{2} / \mathrm{s}$ \\
\hline Heat transfer coefficient & $\alpha$ & 10 & $\mathrm{~W} / \mathrm{m}^{2} \mathrm{~K}$ \\
\hline Conductivity & $\lambda_{\mathrm{p}}$ & 0.4 & $\mathrm{~W} / \mathrm{m} \mathrm{K}$ \\
\hline Specific heat & $\mathrm{c}_{\mathrm{p}}$ & $3,79.10^{2}$ & $\mathrm{~J} / \mathrm{kg} \mathrm{K}$ \\
\hline Density & $\rho_{\mathrm{p}}$ & 2815 & $\mathrm{~kg} / \mathrm{m}^{3}$ \\
\hline
\end{tabular}

\section{Results and discussions}

The mathematical model of the above pilot dryer with the specified control strategies was implemented in Matlab environment using the Simulink toolbox. The process parameters presented in table 1 were used. The block diagrams of the PID controller is presented in fig. 4. Simulations were conducted for a step change in the input drying air temperature and the results presented in fig. 5 to fig. 8 .

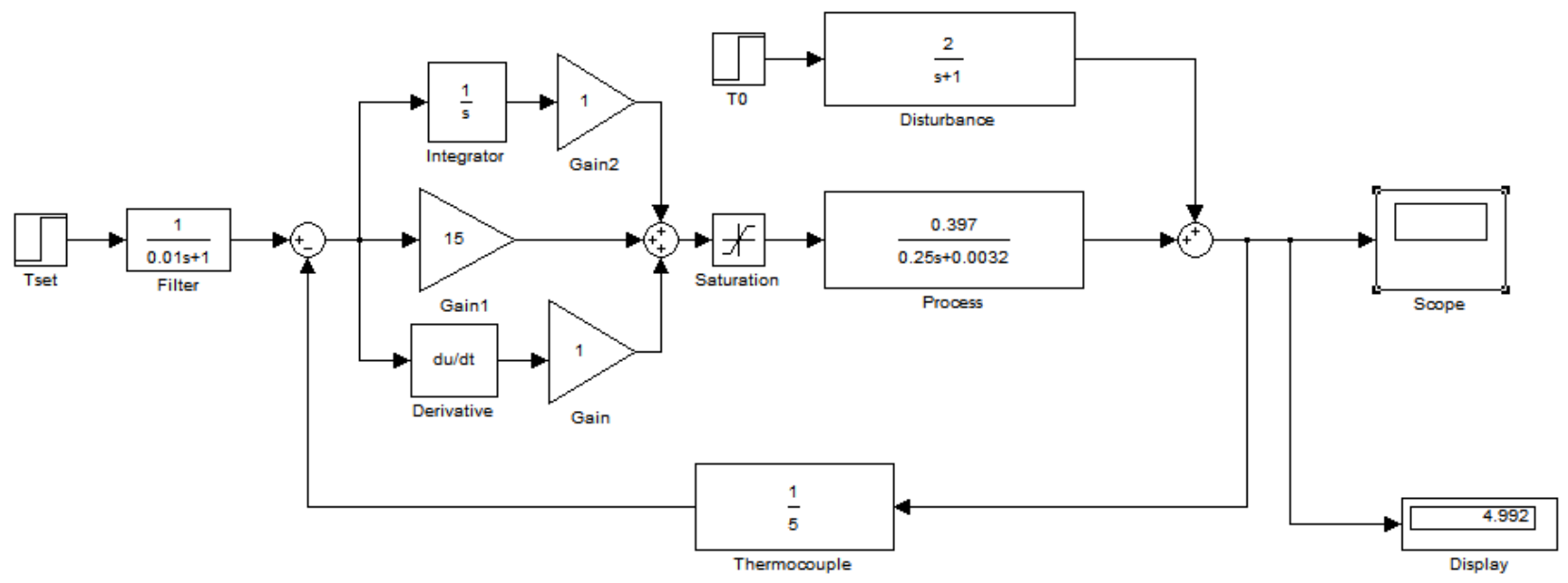

Fig. 4. Block diagram of the feedback controller in Simulink

Simulation were conducted on the closed-loop system to track the desired set point of the output beans temperature. The controller quickly reached steady state even after introducing a step change of disturbance (fig. 5 and 6). Further test also shows that the controller is able to show remarkable resistance to both minor and major input and output disturbances (fig. 7 and 8). 


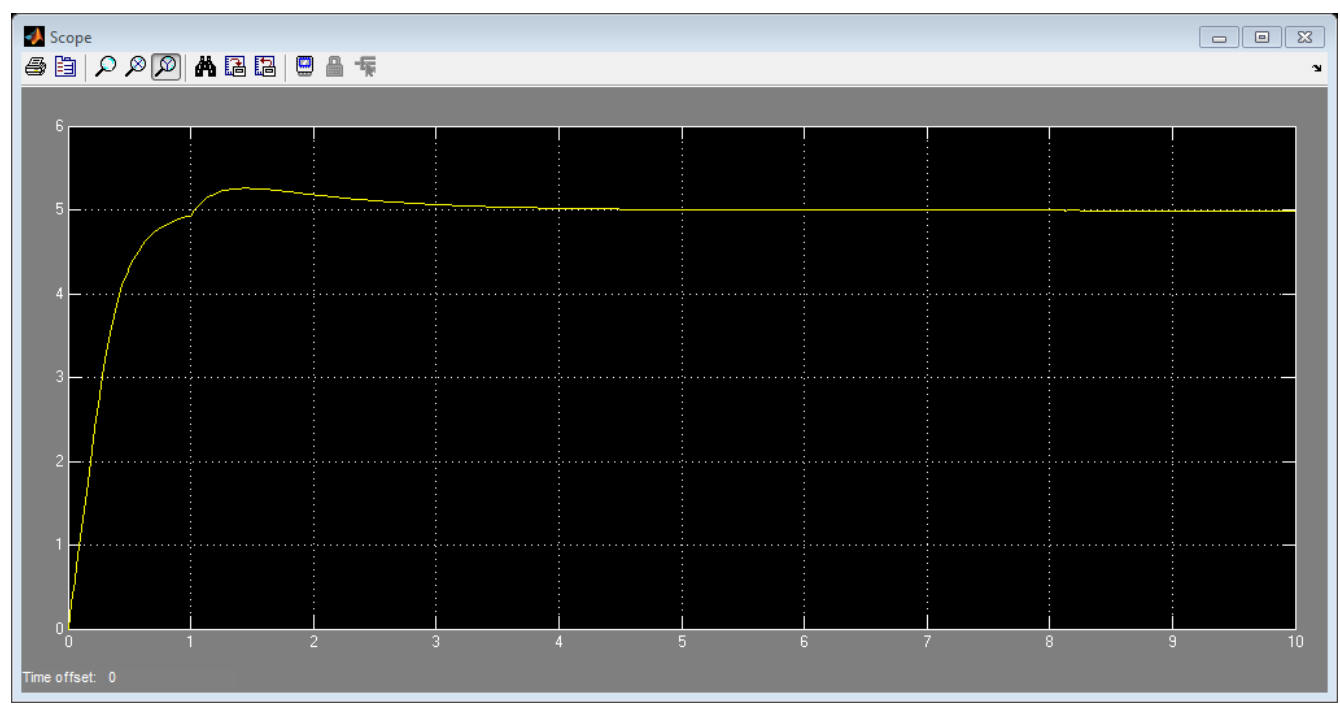

Fig. 5. The controller response plot in Simulink simulation

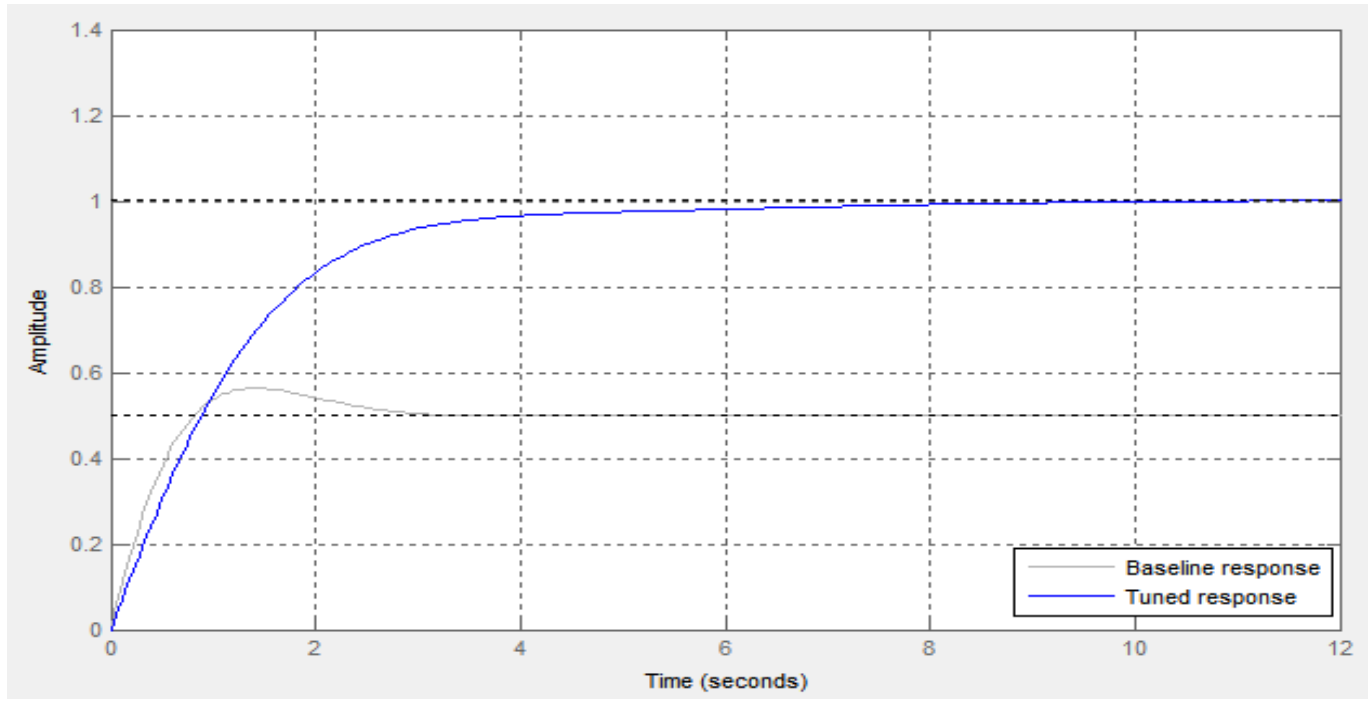

Fig. 6. Manually tuned controller response plot 


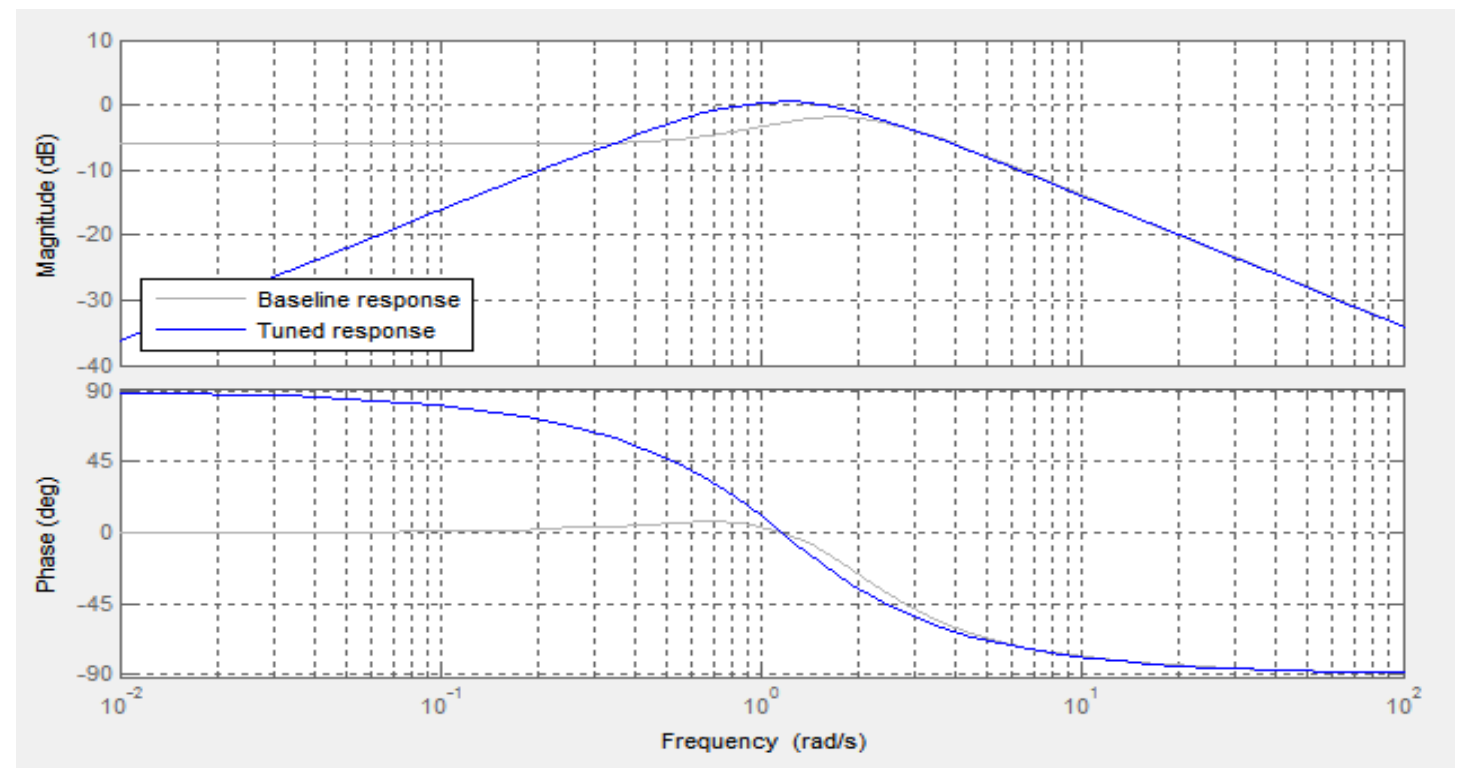

Fig. 7. Bode plot of input disturbance rejection
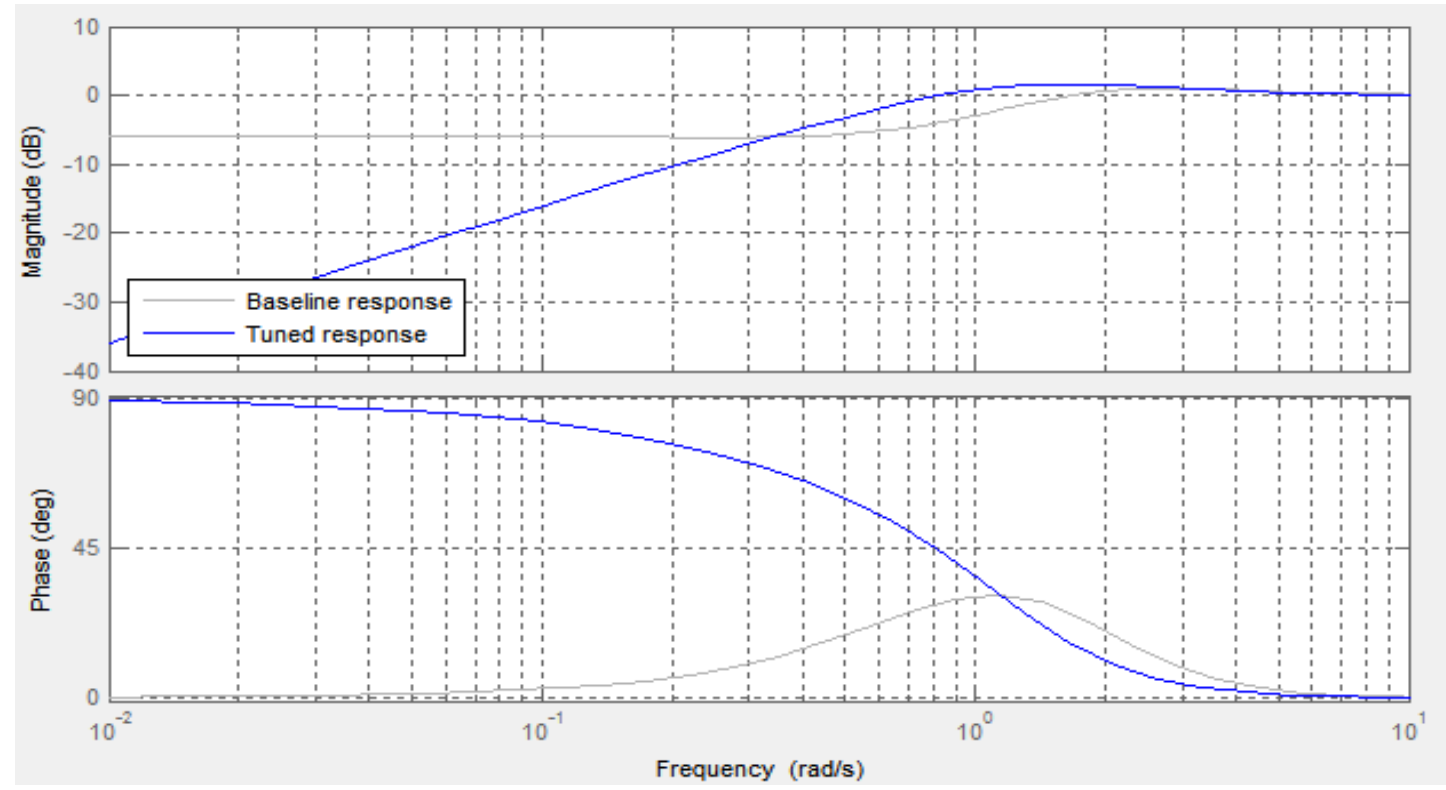

Fig. 8. Bode plot of output disturbance rejection 


\section{Conclusion}

Thermal treatment processes such as roasting and drying are very energy intensive and considering the ever-increasing cost of energy, there is the need for continuous process improvement in order to reduce operational cost, while maintaining or improving the quality of the end cocoa products.

This work describes the design, simulation and Implementation of an automated control system ACS based on a PID controller algorithm with a negative feedback for the control of the thermal treatment of cocoa beans in a conveyor belt dryer.

The thermal treatment processes is modelled as a continuous, spatially distributed single input single output system (SISO) where the control variables is the voltage flow to the electric heater (temperature of the drying air) and the controlled variable the product temperature in the drying chamber. Software and hardware requirements of the ACS were also presented and discuss. Numerical simulations of the ACS were carried out using Matlab and Simulink.

Overall, the numerical simulation results show that the PID controller is stable and robust in terms of input disturbance rejection. The system provides relatively fast response in terms of eliminating offset and steady state error in the thermal treatment process. 


\section{REFERENCES}

1. D. C. Akmel, N. E. Assidjo , P. Kouamé and K. B. Yao K, "Mathematical Modelling of Sun Drying Kinetics of Thin Layer Cocoa," vol. 5(9), pp. 1110-1116, 2009.

2. P. M. Bradley, Thermal Processing of Foods: Principles and Applications, Handbook of Food Science, Technology, and Engineering, vol. 3, CRC Press, 2006.

3. ADM Cocoa, "De Zaan Cocoa and Chocolate Manual. 40th anniversary edition," 2009.

4. Mujumdar, A S. (Ed), Handbook of Industrial Drying, 2nd ed., New York: Marcel Dekker, 2006, pp. 20-31.

5. S. Mujumdar and L. X. Huang, "Global R\&D Needs in Drying," Drying Technology: An International Journal, vol. 25, no. 4, pp. 647-658, 2010.

6. Mujumdar, A. S., R\&D Needs, Challenges and Opportunities for Innovation in Drying Technology, 2010.

7. B. V. Palyukh, "Osnovy postroeniya i razrabotki avtomatizirovannoy sistemy upravleniya ekspluatatsionnoy nadezhnost'yu khimicheskikh proizvodstv," M, 1991.

8. H. Mansor, S. B. Mohd Noor, R. K. Raja and F. S. Ahmad, "Intelligent control of grain drying process using fuzzy logic controller," Journal of Food, Agriculture \& Environment, vol. 8, no. 2, pp. 145-149, 2010.

9. F. F. G. Areed, M. S. El-Kasassy and K. A. Mahmoud, "Design of Neuro-Fuzzy Controller for a Rotary Dryer," International Journal of Computer Applications, vol. 37, no. 5, 2012.

10. V. V. Kafarov, , I. N. Dorokhov and L. N. Lipatov, Sistemnyy analiz protsessov khimicheskoy tekhnologii. Statisticheskie metody identifikatsii v khimicheskoy tekhnologii, M: Nauka, 1982, p. 344.

11. M. N. Puchkov, "Sreda avtomatizirovannogo modelirovaniya sushil'nykh apparatov.," RKhTU im. D.I.Mendeleeva, M, 2002.

12. S. A. Nikel', "Povyshenie effektivnosti protsessa teplovoy Obrabotki kakao - bobov i arakhisa," VGTA, Voronezh, 2002.

13. O. M. Chaykin, "Upravlenie barabannymi sushil'nymi ustanovkami s retsirkulyatsiey vysushivaemogo materiala (na primere sushki tekhnicheskogo ugleroda)," Yaroslavl', 2010.

14. M. N. Prokopenko, "Avtomatizatsiya tekhnologicheskogo protsessa sushki keramicheskogo kirpicha na osnove mnogosvyaznykh (odnotiinykh sistem unravleniya)," Tambov, 2007.

15. T. M. Kyi, . R. W. D. Wan, A. B. Mohammad, M. W. Samsudin, A. A. H. Kadhum and M. Z. M. Talib, "The kinetics of polyphenol degradation during the drying of Malaysian cocoa beans," no. 40, p. 323-331, 2005.

16. L. Cammarata and L. Yliniemi, "Development of a Self-Tunning Fuzzy Logic Controller for a Rotary Dryer," University of Oulu, 1999.

17. k. Sandeep, "Temperature Control of CSTR using PID and PID (Two Degree of Freedom) Controller," IJARCSSE, vol. 2, no. 5, pp. 326-329, May 2012.

18. . S. S. Mohd, J. Hishamuddin and . Z. M. D. Intan, "Implementation of PID controller tuning using differential evolution and genetic algorithms," Intenation journal of 
innovative computing, information and control, vol. 8, no. 11, pp. 7761-7769, november 2012.

19. S. S. Mohd, J. Hishamuddin and Z. M. D. Intan, "PID Controller Tuning Using Evolutionary Algorithms.," WSEAS transactions on systems and control, vol. 7, no. 4, pp. 139 -149, October 2012.

20. M. N. Ozisik, Heat conduction, John Wiley \& Sons, 1993, p. 356.

21. M. Vajta, "A New Model Reduction Technique for a Class of Parabolic Partial Differential Equations," in IEEE Int. Conference on Systems and Engineering, Dayton, Ohio, USA, 1991.

22. M. Vajta, "Nyquist stability test for a parabolic partial differential equation," in IASTED Conf. on Modeling, Identification and Contro, Innsbuck, Austria, 2000.

23 D. Olurotimi, A. M. Montaz, . O. P. Jimoh and D. Muhammed, "Differential EvolutionBased PID Control of Nonlinear Full-Car Electrohydraulic Suspensions," Hindawi Publishing Corporation Mathematical Problems in Engineering, vol. 261582, p. 13, 2013. 
УДК 007

Чохонелидзе Александр Николаевич

Тверской государственный технический университет

Россия, Тверь ${ }^{1}$

Профессор

Доктор технических наук

E-mail: a444595@pochta.ru

Форгор Лемпого

Тверской государственный технический университет

Россия, Тверь

Аспирант

Ганский университет технологии

Гана, Аккра

Преподаватель

E-mail: forlempo@yahoo.co.nz

Виллиам Браун-Аквей

Тверской государственный технический университет

Россия, Тверь

Аспирант

Ганский университет технологии

Гана, Аккра

Преподаватель

E-mail: wbrownacquaye@ hotmail.com

\section{Автоматизированное управление процессом термообработки какао-бобов с использованием ПИД-регулятора}

1 170024, Тверь, Проспект Ленина, 25 
Аннотация. Процессы термообработки какао-бобов, такие как сушки и обжарки являются очень энергоемкими и в связи с чем, уменьшение энергозатрат, требуемых для термообработки, при сохранении или повышении показателей качества конечных какаопродуктов является одним из важных отраслевых задач. Работа посвящена разработке и моделированию автоматизированной системы управления АСУ на основе алгоритма ПИДрегулятора для управления процессом термообработки какао-бобов в сушилке конвейерной ленты. Процесс термообработки рассматривается как непрерывная пространственнораспределенная система с одним входом и одним выходом, в которой управляющей переменной является температура входного сушильного газа и регулируемой переменной, температура бобов в сушильной камере. Также были представлены и обсуждены программное и аппаратное требование САУ. Численное моделирование САУ было проведено в среде Matlab с использованием инструментарий Simulink. В целом, результаты численного моделирования показывают, что предложенный ПИД-регулятор является стабильным и надежным с точки зрения отказа от входных возмущений. Система обеспечивает относительно быстрое реагирование в плане устранения смещения и статическую ошибку в процессе термообработки.

Ключевые слова: ПИД-регулятор; термообработка; какао; автоматический контроль; стратегия управления; математическое моделирование. 


\section{ЛИТЕРАТУРА}

1. D. C. Akmel, N. E. Assidjo , P. Kouamé and K. B. Yao K, "Mathematical Modelling of Sun Drying Kinetics of Thin Layer Cocoa," vol. 5(9), pp. 1110-1116, 2009.

2. P. M. Bradley, Thermal Processing of Foods: Principles and Applications, Handbook of Food Science, Technology, and Engineering, vol. 3, CRC Press, 2006.

3. ADM Cocoa, "De Zaan Cocoa and Chocolate Manual. 40th anniversary edition," 2009.

4. Mujumdar, A S. (Ed), Handbook of Industrial Drying, 2nd ed., New York: Marcel Dekker, 2006, pp. 20-31.

5. S. Mujumdar and L. X. Huang, "Global R\&D Needs in Drying," Drying Technology: An International Journal, vol. 25, no. 4, pp. 647-658, 2010.

6. Mujumdar, A. S., R\&D Needs, Challenges and Opportunities for Innovation in Drying Technology, 2010.

7. Б. В. Палюх, "Основы построения и разработки автоматизированной системы управ-ления эксплуатационной надежностью химических производств," M, 1991.

8. H. Mansor, S. B. Mohd Noor, R. K. Raja and F. S. Ahmad, "Intelligent control of grain drying process using fuzzy logic controller," Journal of Food, Agriculture \& Environment, vol. 8, no. 2, pp. 145-149, 2010.

9. F. F. G. Areed, M. S. El-Kasassy and K. A. Mahmoud, "Design of Neuro-Fuzzy Controller for a Rotary Dryer," International Journal of Computer Applications , vol. 37, no. 5, 2012.

10. В. В. Кафаров, , И. Н. Дорохов аnd Л. Н. Липатов, Системный анализ процессов химической технологии. Статистические методы идентификации в химической технологии, М: Наука, 1982, р. 344.

11. М. Н. Пучков, "Среда автоматизированного моделирования сушильных аппаратов.," РХТУ им. Д.И.Менделеева, М, 2002.

12. С. А. Никель, "Повышение эффективности процесса тепловой Обработки какао бобов и арахиса," ВГТА, Воронеж, 2002.

13. О. М. Чайкин, "Управление барабанными сушильными установками с рециркуляцией высушиваемого материала (на примере сушки технического углерода)," Ярославль, 2010.

14. М. Н. Прокопенко, "Автоматизация технологического процесса сушки керамического кирпича на основе многосвязных (однотииных систем унравления)," Тамбов, 2007.

15. T. M. Kyi, . R. W. D. Wan, A. B. Mohammad, M. W. Samsudin, A. A. H. Kadhum and M. Z. M. Talib, "The kinetics of polyphenol degradation during the drying of Malaysian cocoa beans," no. 40, p. 323-331, 2005.

16. L. Cammarata and L. Yliniemi, "Development of a Self-Tunning Fuzzy Logic Controller for a Rotary Dryer," University of Oulu, 1999.

17. k. Sandeep, "Temperature Control of CSTR using PID and PID (Two Degree of Freedom) Controller," IJARCSSE, vol. 2, no. 5, pp. 326-329, May 2012.

18. . S. S. Mohd, J. Hishamuddin and . Z. M. D. Intan, "Implementation of PID controller tuning using differential evolution and genetic algorithms," Intenation journal of 
innovative computing, information and control, vol. 8, no. 11, pp. 7761-7769, november 2012.

19. S. S. Mohd, J. Hishamuddin and Z. M. D. Intan, "PID Controller Tuning Using Evolutionary Algorithms.," WSEAS transactions on systems and control, vol. 7, no. 4, pp. 139 -149, October 2012.

20. M. N. Ozisik, Heat conduction, John Wiley \& Sons, 1993, p. 356.

21. M. Vajta, "A New Model Reduction Technique for a Class of Parabolic Partial Differential Equations," in IEEE Int. Conference on Systems and Engineering, Dayton, Ohio, USA, 1991.

22. M. Vajta, "Nyquist stability test for a parabolic partial differential equation," in IASTED Conf. on Modeling, Identification and Contro, Innsbuck, Austria, 2000.

23. D. Olurotimi, A. M. Montaz, . O. P. Jimoh and D. Muhammed, "Differential EvolutionBased PID Control of Nonlinear Full-Car Electrohydraulic Suspensions," Hindawi Publishing Corporation Mathematical Problems in Engineering, vol. 261582, p. 13, 2013. 